\title{
A meta-analysis of hate speech in Indonesia The yielding of academic discourse to the discourse of authority
}

\begin{abstract}
This article focuses on academic publications about hate speech within Indonesia's scholarly context. The authors analyse the ongoing discourse on hate speech by conducting a meta-analysis method on 'Garuda', an official website designed as a repository of scholarly publications in Indonesia. By examined 143 scientific articles, this study found that most studies refer to the definition of hate speech from the Circular No. SE/06/X2015 on hate speech issued by the Indonesian National Police. This shows how most Indonesian academics were comfortable with a limited perspective on hate speech. Furthermore, the variety of studies on hate speech comes from law or legal studies and communication or da'wah communication. Most Indonesian academics also conducted studies on hate speech with a juridical normative approach, as well as qualitative research. Furthermore, some studies have been done with unclear methods and approaches. Academics ideally should serve the people by being critics of power and government apparatus, for example by continuing to question how hate speech is studied, including in the context of its definition and how it affects the implementation in Indonesia. Hence, the authors urge Indonesian academics to do more studies on hate speech from various backgrounds with more rigorous and various research methods to be able to expand knowledge about hate speech cases in Indonesia.
\end{abstract}

Keywords: communication, defamation, discourse analysis, freedom of expression, freedom of speech, hate speech, hate speech policy, Indonesia, internet, meta-analysis, social media

\author{
JUSTITO ADIPRASETIO \\ KUNTO ADI WIBOWO \\ DETTA RAHMAWAN \\ Universitas Padjadjaran, Bandung, Indonesia
}

\section{Introduction}

NTENSE international debates have been occurring about hate speech around the world (Heinze, 2016). The scope of discussion spans from its relation to freedom of expression and freedom of speech where any regulation and 
attempts to limit hate speech are seen as a contradiction with particular notions such as the individual's right to express an opinion (Yong, 2011; Bleich, 2013; Bangstad, 2014; Heinze, 2016) and normative law (Brown, 2015). Furthermore, academic discourse on news media, such as the internet and social media, have also contributed to the escalation of studies on hate speech (Brown, 2017; Pohjonen \& Udupa, 2017; Ross, 2018; Cohen-Almagor, 2018).

In Indonesia, hate speech studies have increased since 2015, especially after the national police issued Circular No. SE/06/X2015 on hate speech (hereafter referred to as 'HS Circular'). Such a circular has proven to have a significant influence, especially on academic discourse related to hate speech in Indonesia. At least in the range of April 2015-October 2019, after the issuing of the circular, 41 articles were published in scientific journals in Indonesia, which were identified through 'Garuda' a repository for Indonesian scientific articles (Adiprasetio \& Wibowo, 2020). Before the the circular was issued, there was only one article which studied hate speech. Hence, it can be said that the HS Circular issued by the national police has to some extent affected the academic conversations related to hate speech. In 2015, various sides were concerned about the issuance of the HS Circular by the police since the regulation included catchall articles - namely 310 and 311 of the Criminal Code (KUHP) regarding defamation (Firdaus, 2015). In Indonesia, this has been colloquially referred to as pasal karet, or 'rubber clauses'. Furthermore, some lawyers have called for the revocation of the HS Circular for the following reason:

[HS Circular] could cause misperceptions in society, particularly because it could be considered as a limitation of the freedom of expression...The forms of hate speech mentioned are the same as those stipulated in the Criminal Code, including libel, defamation, unpleasant conduct, provocation, inciting violence and spreading lies...[and] the police did not need to issue such a circular in the first place because regulations on hate speech were found in a number of articles in existing regulations. (The Jakarta Post, 2015).

These lawyers warn that the obfuscation of the hate speech definition has the potential to make all forms of violations of the law mentioned above (ie: libel, defamation, unpleasant conduct, provocation, inciting violence and spreading lies) to be categorised as hate speech. In addition, the circular also stated that the police would 'prioritise the function of guidance to conduct counselling or outreach to the community regarding hate speech and the negative impacts that will occur', in which the government definition of hate speech which was formulated arbitrarily and caused various concerns will be used as an authoritative source for information to the wider public (Purnomo, 2020). Furthermore, relating to online communication, Indonesia has a specific law or undang-undang 
(UU) concerning Information and Electronic Transactions (ITE). This lawUU No. 112008 which was later revised to Act No. 19, 2016-regulates online hate speech and defamation where it also refers to articles 310 and 311 of the Criminal Code (KUHP). Unclear definition of hate speech in the online context also became a threat to democracy and freedom of expression. More than half of the cases on the violation of ITE Law during 2014-2019 were being categorised as 'hate speech' and 'insults' towards the president (Hamid, 2019).

Furthermore, prevention of hate speech is also repeatedly used as a basis for taking excessive action against the democratic movement such as the enforcement of internet blackouts during protests in Papua after an attack on Papuan student dormitories in Surabaya; the dissolution and arrests of protesters and activists in Jakarta and Bandung that enforced the controversial Omnibus Law which allegedly only benefits the oligarchs and various other incidents (Idris, 2019; Nastiti, 2020; Permana \& Ferdinan, 2020). Since the enactment of the ITE Law, the police have handled 1,338 cases in 2017,2,552 cases in 2018, and 3,005 cases until October 2019 which shows an increase in the number of cases that occur each year. The most used articles in the law to report the cases are article 27 paragraph 3 of the ITE Law (Defamation) followed by article 28 paragraph 2 (on hatred). The ITE Law has also been used arbitrarily for the advantage of the government, according to one of the organisations in Indonesia which works to monitor digital rights in Indonesia, SAFEnet, as follows.

The emergence of public officials and state apparatus as perpetrators of criminalization, shows that the ITE Law has increasingly been wrongly used to silence critical voices of public policy. Criminalisation in the digital world is in line with the increasing repressive acts toward citizens who voiced their aspirations in the middle of the political year and afterwards. (SAFEnet, 2020, p. 21)

Thus far there are no comprehensive meta-analysis studies which systematically examine the ongoing development of academic research related to hate speech in Indonesia. The purpose of this article is to present a referential framework related to the definition of hate speech from the production and reproduction of scientific publications on hate speech in Indonesia after the issuance of the HS Circular. Consequently, this article tries to describe the connection between academic discourse and authoritative discourse from government officials. Within this regard, this article also tries to contextualise how hate speech definitions around the world have always been debatable and there is no single perspective on hate speech that works universally. There is always negotiation in the effort to define and categorise hate speech which involves various disciplines, ranging from applied linguistics, law, discourse analysis, sociology, social psychology to communication studies (Brown, 2015; Paz et al., 2020). 
In addition, until now, there have been very limited social science studies using meta-analysis in an Indonesian context. Hence, we argue that there are difficulties in mapping the variety of studies that have been carried out by Indonesian social scientists. This study seeks to fill the gap and enrich the horizons of metaanalysis research in Indonesia.

\section{Method}

It can be said that in modern science, advancement will rely on generalizations that can be drawn from previous studies. The achievements and explorations that have been carried out by researchers in particular fields can become the parameters of the development of those fields (Kamhawi \& Weaver, 2003). In this context, the reference for the meta-analysis method we use are primarily those in the context of communication research, as a field that sees hate speech as an act of communication (Rains et al., 2020). Meta-analysis generally refers to an approach to summarize the mapping of research quantitatively using various statistical methods There has been considerable attention by American and European scholars to the meta-analysis approach. It has been said that metaanalysis can enrich the study of communication science if it is carried out in various scopes of study (Borenstein et al., 2009; Hunter \& Schmidt, 2014).

Early promoters of the meta-analysis approach, Alice H. Eagly and John E. Hunter in the 1990s trained doctoral students who focused on the scope of communication research. Eagly and Hunter and their students compiled several volumes of meta-analyses in a broad field of communications research (Johnson et al., 2008), including persuasion (Allen \& Preiss, 1998), interpersonal communication (Gayle et al., 2002) mass communication (Kamhawi \& Weaver, 2003 ) as well as an evolving meta-analytical approach to one of the fast-growing sub-disciplines of communication science - health communication (Noar, 2006). Along with many other outputs, the Communications Yearbook in particular welcomes meta-analytic reviews. The International Communications Association annually presents the John E. Hunter Memorial Award for the best meta-analysis in communications (Johnson et al., 2008).

A limited number of systematic reviews of research and/or meta-analysis studies in Indonesia make it very difficult to measure achievements by scholars of communication science in Indonesia (Bajari, 2017). This is inversely proportional to studies in Europe and the United States. Since the first two publications with a meta-analysis approach were published in communication journals in 1984 (Boster \& Mongeau, 1984), which appear in journals of the International Communication Association, including the journal Human Communication Research, communication scholars in Europe and America are starting to use meta-analysis. In the period of 1984 to 2005,150 articles were published using the meta-analysis method. There are at least three articles that use a meta-analysis 
approach per year in this three-decade period (Rains et al., 2018). Meanwhile, between 2006 and 2015, this figure increased to more than eight meta-analyses per year (Rains et al., 2020).

Most meta-analysis studies in America tend to focus on examining the consistency of the relationship and influence between variables in a particular study area. This is of course due to the attention of American scholars towards quantitative studies in various fields (Kamhawi \& Weaver, 2003; Kim et al., 2014; Taipale \& Fortunati, 2014). This situation is very different from that in Indonesia, where existing studies in various sciences of communication studies are likely to be dominated by studies using a qualitative approach. One that is highly likely to be adopted by scholars of communication science in Indonesia is to apply a qualitative meta-analysis approach. The qualitative approach to meta-analysis itself has been developed in many branches of science (Paterson et al., 2001), and several parallel approaches were developed in sociology since the 1950s and subsequently developed in the early 1990s (Ritzer, 1990). Furthermore, in recent decades several versions of qualitative meta-analysis have been used in sociology (Zhao, 1991) and anthropology (Kaplan \& Mack, 2010).

This article uses a meta-analysis method to analyse 143 scientific articles published in various scientific journals of educational institutions in Indonesia. The data is compiled from the portal garuda.ristekdikti.go.id, which is a platform created by the Ministry of Research and Technology, Indonesia for searching for Indonesian scientific articles (Subroto, 2014). Such a platform is perceived as a place for authoritative scientific publications in Indonesia. The criteria for articles that are included are articles that use hate speech terminology and/or hate speech in the title or its abstract. After the articles were collected, they were categorised or coded according to four broad frameworks: scientific disciplines, references to hate speech, methodology and research methods.

The categorisation process was carried out by two coders to classify articles based on four variables with each category. Scientific discipline is divided into eight categories; Law, Communication and/or Da 'wah Communication (propagation of Islamic teaching), Religion, Informatics and/or Computer Science, Language/Linguistics and Non-Communication Social Sciences, while the other three variables of references to hate speech, methodology and research method are categorised as inductive coding based on the findings contained in each article. All data encoded by the two coders were then tested with the intercoder reliability test using Krippendorf's $\alpha$, which met or exceeded .80 for all variables, and after discussion, complete agreement was reached on low-incidence categories (Hayes \& Krippendorff, 2007; Krippendorff, 2011).

\section{Results and discussion}

Based on the analysis from all abstracts of publications in the Indonesian language on the Garuda Portal in the past decade, it can be seen that in the period 
before 2014, there were no publications that used the term 'hate speech'. Hate speech only entered this forum of academic discourse in 2014 through Ahnaf \& Suhadi's article (2014) entitled Isu-Isu Kunci Ujaran Kebencian (Hate Speech): Implikasinya terhadap Gerakan Sosial Membangun Toleransi (Key Issues of Hate Speech: Implications for Social Movements on Building Tolerance), which was published in Jurnal Harmoni belonging to the Ministry of Religion of the Republic of Indonesia. The article discusses how to formulate appropriate policies for hate speech regulations in Indonesia. This is important since hate speech presents a challenge for the democratisation process in Indonesia, especially in relation to religious freedom for and tolerance of religious minorities. However, on the other hand, the law enforcement process against hate speech risks restoring the repression that happened in the New Order period, where the categories of SARA (Suku, Agama, Ras, Antar-Golongan or Ethnicity, Religion, Race, Inter-Group Relations) were used to suppress political opposition (Ahnaf \& Suhadi, 2014). After the national police issued the HS Circular in 2015, scientific publications related to hate speech increased rapidly. In 2015, two articles were published; in 2016, six articles were published; in 2017 the number doubled compared to the previous year, with 12 articles; in 2018 it nearly tripled compared to the previous year, with 34 articles; and in 2019 the number of articles continued to increase again with 55 articles in one year. Only in 2020, has the quantity decreased to 33 articles (Figure 1).

In the same month as the publication of the HS Circular, in October 2015 an article was published discussing the existence and legal position of the circular as a technical reference or guideline for taking action against hate speech (Ryanto, 2015). Two months later, in December, an article was published discussing the handling of HS circular within the framework of human rights (Anam \& Hafiz, 2015 ) in which there is a recommendation for the handling of suspects of hate speech which must first be based on an assessment of context; speakers/actors; intention; messages or content; and procedure or the form of delivering messages. However, in general, Anam and Hafiz (2015) did not problematise the definitions and criteria of hate speech used in the HS Circular.

The problem of defining hate speech was outlined in a case relating to defamation that befell Prita Mulyasari in 2008 when her personal email protesting against the misdiagnosis by Omni International Hospital was spread on social media (Wisnu \& Wulandari, 2009). The broadness of the definition of defamation allows legal clauses relating to legal claims of defamation to be misused, as happened to Prita. Therefore, it is also possible that having too broad a definition of hate speech could also lead to the Circular being misused. In a similar case in 2019, the Mimika police in Papua arrested AY, a worker at the gold and copper miner PT Freeport Indonesia, for making a video that police have described as 'hate speech against Indonesia' and distributing it on social media. AY made a 
Figure1: Indonesian publications on hate speech

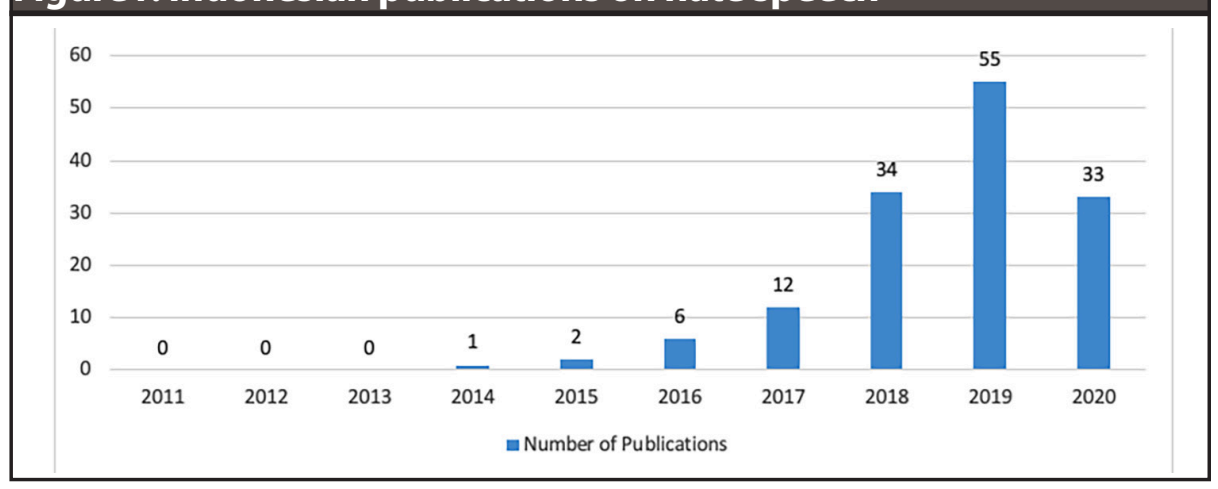

short video of his young son expressing opposition to Indonesia's sovereignty over Papua, and the video was then posted on Facebook (The Jakarta Post, 2018). Despite the police not arresting the child, it set a precedent that the hate speech as a category can be used to limit freedom of expression. The problem of hate speech definition was repeated in a third case in 2020 when 'Jerinx' (I Gede Ari Astina, a Balinese musician who is part of the punk-rock band Superman Is Dead) criticised the Indonesian Medical Association (IDI) in terms of handling the spread of the COVID-19 pandemic. Jerinx called them 'WHO lackeys' and indicated that women and babies were at risk of dying due to the Rapid COVID-19 tests. He was sentenced to one year and two months in prison by a panel of judges at the Denpasar District Court, Bali, over hate speech (Channel News Asia, 2020; KumparanNews, 2020).

Increasingly, a broad definition of hate speech does not only target individuals as in the cases of Prita Mulyasari, AY and Jerinx, but also Indonesia's democratic progress. One example is the arrest and persecution of demonstrators in August 2019 in Papua, at a demonstration initially sparked by acts of racism and attacks on student dormitories in Surabaya. In addition to the arrests, the prevention of hate speech was used as the basis for the Indonesian authorities to implement a total internet blackout throughout Papua on 22 August 2019. The blackout continued until 6 September when it was partially lifted for several regions, with the complete lifting of the blackout only occurring on 11 September 2019. Despite broad criticism from human rights activists, reporters, and Papuan civilians realising their daily activities was severely hindered by the blackout, Indonesian authorities defended the decision as necessary to prevent the spread of hate speech that may worsen the protests (Setkab, 2019). Apart from this major event, the police dispersal and violence against Deiyai students in Jayapura city was also based on allegations that students who were conveying their aspirations had committed hate speech. In fact, based on the available testimonies and video evidence, those who pronounced profanities first came 
from the police, not from the protesters (Agapa, 2020). In the end, hate speech becomes a political category that is vulnerable to being used by those in power.

From the 20 earliest scientific publications in Bahasa Indonesia that were published after the publication of HS Circular in the 2015-2017 period, 11 articles specifically used the circular as the focus of the research. Almost all articles in that period tried to explain juridical aspects of the circular (e.g., Kusuma \& P. Lubis, 2016; Mangantibe, 2016; Sari, 2016). From these examples, it can be seen that there is a tendency to primarily rely on the definition of hate speech from the HS Circular without problematising the classification of hate speech. The first 20 publications related to hate speech after the publication of HS Circular were dominated by studies from law or legal studies with nine articles, or from communication studies with six articles; there was only one article each from non-communication fields and informatics.

Most articles discussed the contextualisation of the HS Circular on the eradication of hate speech. Figure 2 shows that the configuration of the first 20 publications did not change much until the end of 2020. Articles written on the topic of hate speech by the end of 2020 totaled 143 . The majority of articles came from the perspective of law or legal studies, amounting to 48 articles or 33.57 percent of total publications. Furthermore, 43 articles or 30.07 percent came from communication science and da'wah communication fields, 18 articles or 12.59 percent came from computer science and informatics, 7 articles or 4.90 percent came from religious studies, and 17 articles or 11.89 percent come from the language and linguistics studies. The remaining 10 articles or 6.99 percent came from other non-communication social sciences.

The influence of juridical discourse is evident in the epistemic field of hate speech, which is indicated by the high number of articles produced by legal studies, beyond the disciplines of communication science and $d a$ ' wah communication, language or linguistics, computer science and informatics, social science and religious studies. Even so, studies that exist within the scope of law as the discipline tend to take a normative perspective, with the consequence that the research questions presented are limited to the objectives and legal justifications for how the police and legal system are handling alleged cases of hate speech, but not at the root of the epistemological basis of hate speech. There is no attempt to question and critically analyse the definition of hate speech applied in the Indonesian jurisdiction.

There is insufficient attention from communications scientists and social scientists to explore the communicative and socio-cultural dimensions on hate speech within Indonesian epistemic discourse. This is worrying since the discourse on hate speech that operates in a particular place or country is dependent on the history of those countries, the lived experience of its people, the sociopolitical situations, and various other factors, including for example how interethnic and inter-religious relations work within a particular context of interaction 


\section{Figure2: Disciplines for hate speech publications}

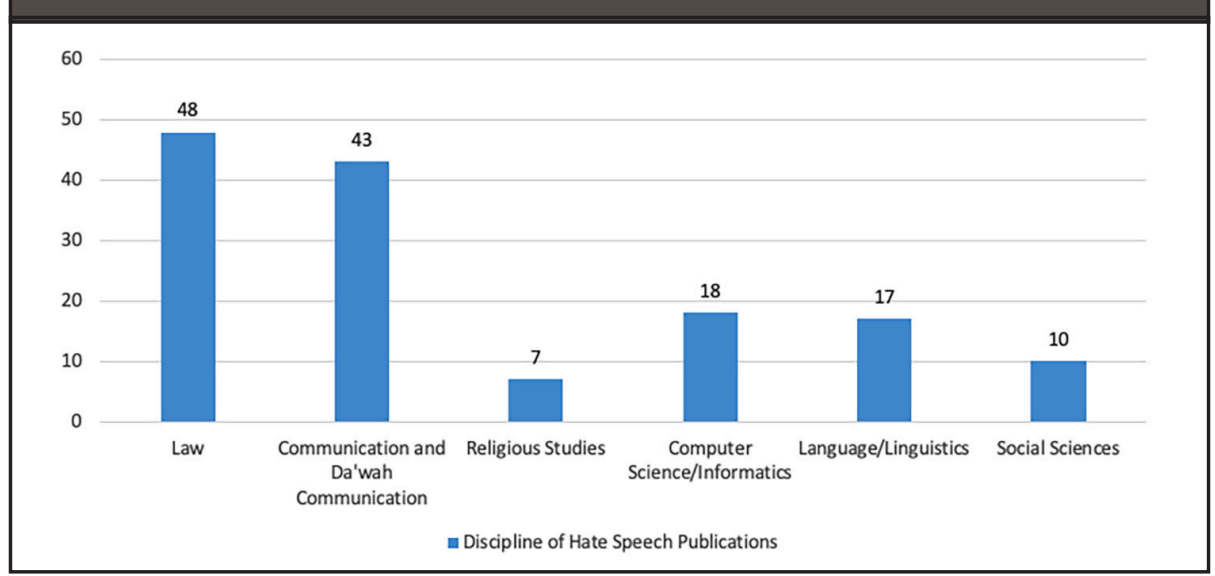

(Baker, 2012; Brown, 2015). The 17 articles from the disciplines of language and linguistics published before the end of 2020 also do not discuss 'expressions' in various conversations related to hate speech, even though expression is related to, for example, differences between hate speech, slander, manipulation, insult, defamation, sarcasm and even irony.

In a period when the actions of people were criminalised by the articles of hate speech that refer to the HS Circular, ITE Law and Criminal Code, Indonesian academics seemed to fail to provide input related to vague definitions of hate speech and irregularities in many hate speech related cases. In-depth, multi-perspective discussions related to hate speech do not get adequate space in the epistemic map of Indonesian science. In fact, there is no article that specifically tries to elaborate on the philosophical and fundamental aspects of hate speech as a definitive category in Indonesian public discourse. This results in the absence of a formulation of definitions and limitations related to hate speech in the context of Indonesian society which is multi-ethnic and has a variety of communicative cultural contexts.

The absence of various discussions regarding the definition of hate speech is also reflected in the reference used for the definition of hate speech which can be seen in Figure 3. A total of 79 articles, or 55.2 percent of the articles used the HS Circular as the main reference for the definition of hate speech. 31 articles, or 21.7 percent used literature sourced from various foreign academics, 21 articles, or 14.7 percent of articles used literature from Indonesian academics. Furthermore, 5 articles, or 3.5 percent used the Council of Europe definition of hate speech, 4 articles, or 2.8 percent used the definition from the International Covenant on Civil and Political Rights (ICCPR), 4 articles, or 2.8 percent used the definition from UNESCO, 4 articles, or 2.8 percent used definitions from the Oxford Dictionary, 3 articles, or 2.1 percent used definitions from The Indonesian 
National Commission of Human Rights (Komnas HAM). Finally, 3 articles or 2.1 percent used articles from the Great Dictionary of Indonesian Language (KBBI), 2 articles, or 1.4 percent used the definition from 'fatwa' or religious rules from Indonesian Ulema Council (Majelis Ulama Indonesia, or MUI) No. 24 of 2017, and one article each used the definition from Black's Law Dictionary and the definition from the Camden Principles on Freedom of Expression and Equality.

Of the 143 articles, there are 31 articles or 21.7 percent, which use Wikipedia or Unclear/Unauthoritative Blogs as the main reference. In fact, 28 articles, or 19.6 percent did not include the literature as a source for the definition of hate speech that was used as a reference. This means that there are studies on hate speech which rely on unclear references, and even without reference to established literature at all. The data shows that the Indonesian academic study on hate speech is not adequately written with coherent analysis, so that the contribution of the study is limited to only describing a particular case or phenomena without providing much needed detailed, comprehensive, and contextual explanations of various aspects related to the hate speech phenomenon. It can be said that this also causes an absence of comprehensive and integrated solutions to solve the problem of hate speech in Indonesia.

The scope of the articles using the HS Circular as a reference shows how authority has a discursive role in defining the map of academic discourse regarding hate speech. Even literature from foreign writers as well as literature from Indonesian writers occupies a position that is not dominant in the basis of defining hate speech. This definitional problem becomes crucial, although several articles were written with the aim of elaborating the position of the HS Circular and the scope of hate speech, but referentially we can see a problem when text produced by the police is used as an authoritative, unquestioned text and becomes the main reference in academic discourse.

Regarding the methodology, in Figure 4, it can be seen that the majority of articles we encountered used qualitative methods, namely 49 articles, or 34.27 percent of the total. Furthermore, quite a number of articles were written with juridical analysis, as many as 36 articles, or 25.17 percent. There were 17 articles with quantitative methods or 11.89 percent. There are 11 articles or 11.89 percent which use programming language/algorithms for analysis. Articles using mixed method amounted to 2 or 1.40 percent. We also found 3 articles or 7.32 percent containing the description of activities, models or concepts related to Community Service (Pengabdian Kepada Masyarakat, or PKM), where articles of this type are usually published in journals that specifically discuss Community Service. The remaining 19 articles, or 13.29 percent, were descriptive articles written without a specific and clear methodology.

Meanwhile, if the various research methods described above are categorised in more detail, it can be seen that normative juridical analysis occupies a dominant 


\section{Figure 3: References for hate speech definitions}

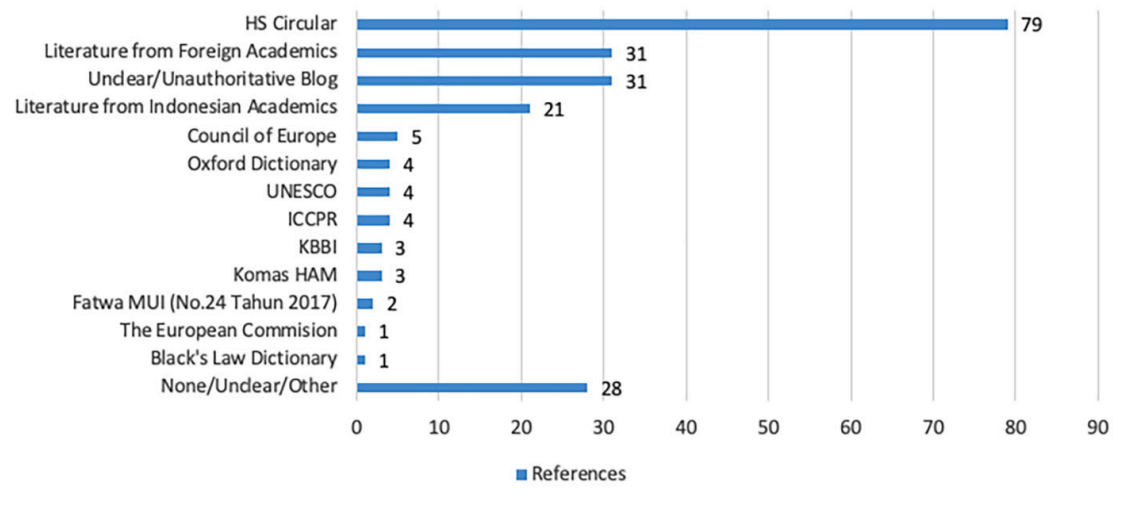

position when compared to other methods comprising 28 articles or 19.6 percent of the total. In the second position is the survey method with 13 articles or 9.1 percent. Furthermore, in third place are 11 articles or 7.7 percent using qualitative descriptive methods. In fourth position are quantitative descriptive analysis with 8 articles or 5.6 percent and in fifth position are articles which are qualitative content analyses with 7 articles or 4.9 percent of all articles related to hate speech, followed by articles using other methods which can be seen in Figure 5 .

Limited references related to hate speech create a fundamental problem on the epistemological map of Indonesia in relation to the discourse of conversation, especially in relation to verbal and symbolic violence. The lack of use of references from previous studies and especially from outside Indonesia, shows that studies related to hate speech in Indonesia are ahistorical and not progressive in analysing hate speech. The dominance of the use of the police definition of hate speech shows that the reproduction of knowledge by the authorities can directly influence academic discourse in Indonesia, and not the other way around. Even when the definition put forward by police clearly obscures the boundaries of hate speech and defamation, this is not discussed as a topic of juridical study or communication and socio-cultural analysis. Hate speech itself in academic discourse outside Indonesia has been discussed in depth, through various perspectives. There is an agreement that although we can provide a definition related to hate speech, the effective analysis of hate speech can only be conducted if we carefully consider the various socio-cultural, political and historical aspects that exist within a particular context (Brown, 2015; Baker, 2012). Unfortunately, amid the chaos and suppression of criticism of the Indonesian government under the banner of limiting hate speech, many academics in Indonesia do not try to contradict or resist with a more nuanced and progressive approach related to hate speech discourse and resistant positions. Academics in Indonesia do indeed place hate speech in 


\section{Figure 4: Methodology of hate speech articles}

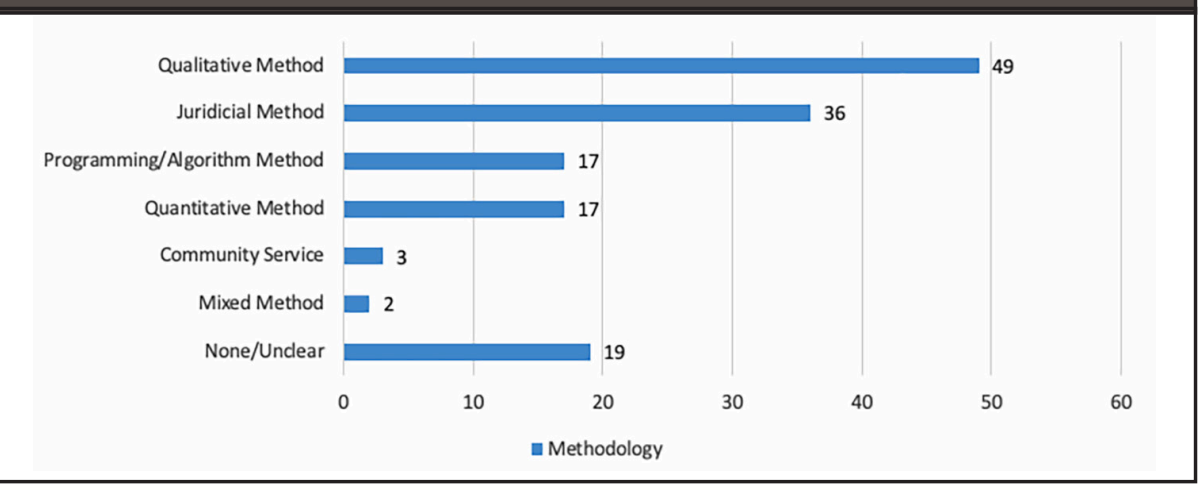

the discourse of research, but what happens is that the definition stipulated by law enforcement appears accepted and reproduced in an uncritical way.

\section{Conclusions}

There are ongoing debates on speech around the world (Heinze, 2016). The debates on hate speech are not only part of legal studies but are also related to the concept of various communication practices. In this context, it is necessary to examine how hate speech is also studied academically, and what kind of discourse exists related to hate speech. This study seeks to map the ongoing discourse on hate speech by conducting a meta-analysis of 143 scientific articles in the Indonesian language published in various scientific journals of educational institutions in Indonesia. The data is compiled from the portal http://garuda.ristekdikti. go.id/, which is a platform created by the Ministry of Research and Technology, Indonesia for searching Indonesian scientific articles (Subroto, 2014).

Our analysis shows that in the period before 2014, there were no publications that used the term 'hate speech'. Hate speech only entered the academic discourse in 2014 and began to develop rapidly in 2015 after the national police issued Hate Speech Circular No. SE/06/X2015. Starting from two articles published in 2015, then six articles in 2016, and then 12 articles in the 2017, 34 articles in 2018, 55 articles in 2019, and 33 articles in 2020. Within this context, it turns out that the HS Circular is the main reference of various academic articles that we have analysed. Some other articles use references from foreign and domestic academic sources, but there are also articles that do not use clear references and instead only refer to non-authoritative sites such as Wikipedia. This suggests that academic discourse related to hate speech in Indonesia is limited and strongly influenced by the HS Circular published by the National Police, even at the level of definitions of hate speech. In addition, this suggests limited exposure to peerreviewed sources within and external to scientific disciplines in the academic 


\section{Figure 5: Hate speech research methods}

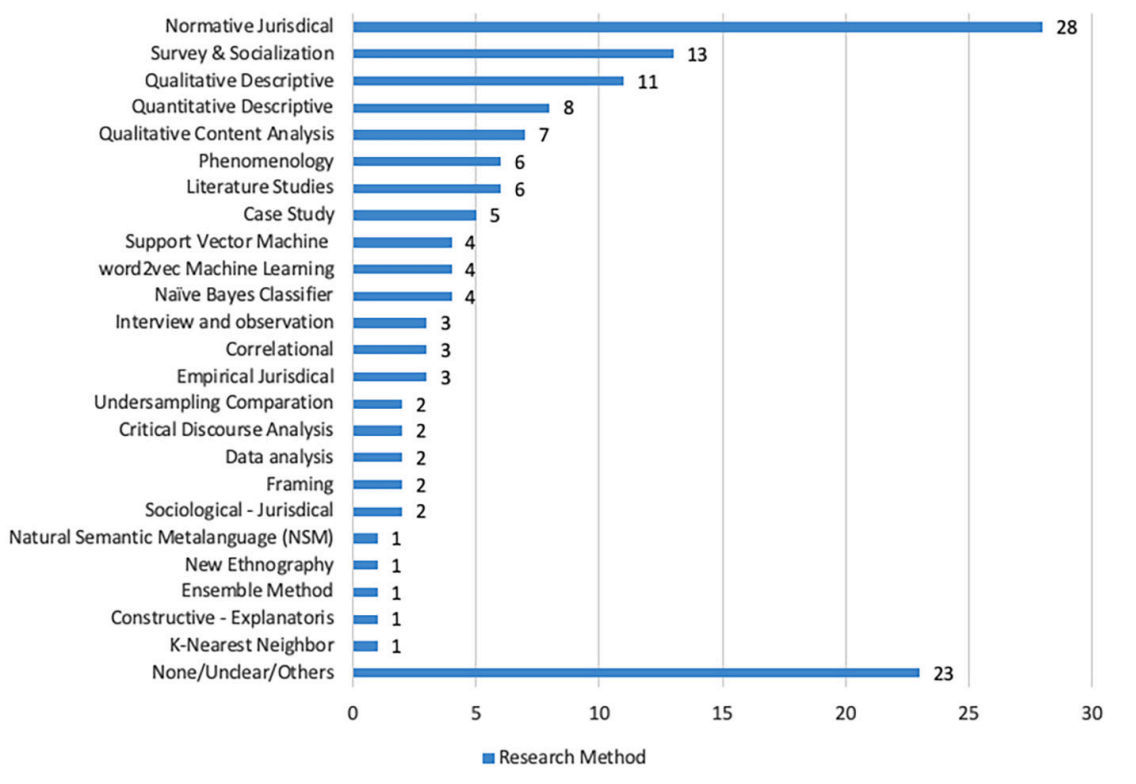

world in Indonesia, and a failure to be able to problematise hate speech more broadly from various perspectives. With definitions of hate speech overlapping with concepts such as defamation, the HS Circular as a catchall source can be used to ensnare political opponents. In this case, articles related to hate speech are often used by authorities to silence critics of the government (SAFEnet, 2020)

Regarding the variants of disciplines that study hate speech, we find that the majority of studies are conducted in the context of the study of law. As to research approaches and methods, the majority of studies on hate speech were conducted with a juridical normative approach, as well as qualitative research. There have been quite a number of studies conducted with unclear approaches which shows that more studies on hate speech from various disciplines using a variety of research methods are urgently needed.

Ideally, in a democratic society, academic discourses should keep an eye on people in power and the government apparatus. Academics should be able to produce and reproduce counter-discourse on hate speech. Without a deep understanding of context, the hate speech circular will continue to ensnare unnecessary victims. Indonesian academics must not only be able to respond to the phenomenon of hate speech in an ontological manner, but further develop an epistemological map of hate speech. This is only possible with serious and in-depth studies of hate speech with methodological rigor and comparison with experiences and analyses that have previously been carried out in other countries. 


\section{References}

Adiprasetio, J., \& Wibowo, K. A. (2020). Diskursus akademik Indonesia terkait hate speech dan sekelumit penjelasan lainnya. Remotivi. Retrieved from https://remotivi. or.id/amatan/565/diskursus-hate-speech-ilmu-pengetahuan-yang-tunduk-pada-suratedaran-aparat

Agapa, Y. (2020). Polisi seret massa aksi disertai hate speech'ke anggota DPRP. Suara Papua. retrieved from https://suarapapua.com/2020/11/20/polisi-seret-massa-aksi-disertai-hate-speech-ke-anggota-dprp/

Ahnaf, M. I., \& Suhadi. (2014). Isu-isu kunci ujaran kebencian (hate speech): Implikasi terhadap gerakan sosial membangun toleransi. Harmoni: Jurnal Multikultural \& Multireligius, 13(3), 153-164.

Allen, M., \& Preiss, R. W. (1998). Persuasion : advances through meta-analysis. Hampton Press.

Anam, M. C., \& Hafiz, M. (2015). Surat edaran kapolri tentang penanganan ujaran kebencian (hate speech) dalam kerangka hak asasi manusia. Jurnal Keamanan Nasional, 1(3), 341-364. https://doi.org/10.31599/jkn.v1i3.30

Bajari, A. (2017). Trends in research on communication and media in Indonesia: The micro meta-analysis on perspective, theory, and methodology. Asian Journal for Public Opinion Research, 5(1), 41-62. https://doi.org/10.15206/ajpor.2017.5.1.41

Baker, C. (2012). Hate speech. In M. Herz \& P. Molnar (Eds.), The content and context of hate speech: Rethinking regulation and responses (pp. 57-80). Cambridge, UK: Cambridge University Press.

Bangstad, S. (2014). Fighting words: What's wrong with freedom of expression. Journal of Ethnic and Migration Studies, 40(2), 266-282.

Bleich, E. (2013). Freedom of expression versus racist hate speech: Explaining differences between high court regulations in the USA and Europe. Journal of Ethnic and Migration Studies, 40(2), 283-300.

Borenstein, M., Hedges, L. V., Higgins, J. P. T., \& Rothstein, H. R. (2009). Introduction to meta-analysis. London, UK: John Wiley \& Sons. https://doi.org/10.1007/978-3319-14908-0 2

Boster, F. J., \& Mongeau, P. (1984). Fear-arousing persuasive messages. Annals of the International Communication Association, 8, 330-375. https://doi.org/10.1080/238 08985.1984 .11678581

Brown, A. (2015). Hate speech law: A philosophical examination. London, UK: Routledge. Brown, A. (2017). What is so special about online (as compared to offline) hate speech? Ethnicities, 18(3), 297-326.

Channel News Asia. (2020). Bali punk rock musician Jerinx detained over allegedly defamatory post about Indonesian Doctors Association. Channel News Asia. Retrieved from https://www.channelnewsasia.com/news/asia/covid-19-indonesia-musicianjerinx-jailed-social-media-post-13593316

Cohen-Almagor, R. (2018). Taking North American white supremacist groups seriously: The scope and the challenge of hate speech on the internet. International Journal of Crime, Justice, and Social Democracy, 7(2), 38-57.

Firdaus, F. (2015). Kontroversi 'hate speech': Dari latar belakang hingga siapa bisa terjerat. Rappler. Retrieved from https://www.rappler.com/world/kontroversi-hatespeech-polri

Gayle, B. M., Preiss, R. W., \& Allen, M. (2002). A meta-analytic interpretation of intimate and nonintimate interpersonal conflict. In M. Allen, R. W. Preiss, B. M. Gayle, \& N. A. Burrell (Eds.), LEA's communication series. Interpersonal communication research: 
Advances through meta-analysis (pp. 345-368). Lawrence Erlbaum Associates.

Hamid, U. (2019). Indonesia's information law has threatened free speech for more than a decade. This must stop. The Conversation. Retrieved from https://theconversation. com/indonesias-information-law-has-threatened-free-speech-for-more-than-a-decadethis-must-stop-127446

Hayes, Andrew F., \& Krippendorff, K. (2007). Answering the call for a standard reliability measure for coding data. Communication Methods and Measures, 1(1), 77-89. https://doi.org/10.1080/19312450709336664

Heinze, E. (2016). Hate speech and democratic citizenship. Oxford, UK: Oxford University Press.

Hunter, J. E., \& Schmidt, F. L. (2014). Methods of meta-analysis: Correcting error and bias in research findings. SAGE Publications, Inc.

Idris, I. K. (2019). The internet shutdown in Papua threatens Indonesia's democracy and its people's right to free speech. The Jakarta Post. Retrieved from https://www. thejakartapost.com/academia/2019/09/02/the-internet-shutdown-in-papua-threatensindonesias-democracy-and-its-peoples-right-to-free-speech.html

Johnson, B. T., Scott-Sheldon, L. A. J., Snyder, L. B., Noar, S. M., \& Huedo-Medina, T. B. (2008). Contemporary approaches to meta-analysis in communication research. In A. F. Hayes, M. D. Slater, \& L. B. Snyder (Eds.), The Sage sourcebook of advanced data analysis methods for communication research (pp. 311-347). SAGE Publications, Inc. https://doi.org/https://doi.org/10.4135/9781452272054.n11

Kamhawi, R., \& Weaver, D. (2003). Mass communication research trends from 1980 to 1999. Journalism and Mass Communication Quarterly, 80(1), 7-27. https://doi. org/10.1177/107769900308000102

Kaplan, J., \& Mack, A. (2010). 'Ethnography of ethnographers' and qualitative metaanalysis for Business. Ethnographic Praxis in Industry Conference Proceedings, 1, 100-112. https://doi.org/10.1111/j.1559-8918.2010.00010.x

Kaz, R. (2018). Hate speech, free speech: The challenges of the online world. Journal of Applied Youth Studies, 2(3), 76-81.

Kim, K., Hayes, J. L., Avant, J. A., \& Reid, L. N. (2014). Trends in advertising research: A longitudinal analysis of leading advertising, marketing, and communication journals, 1980 to 2010. Journal of Advertising, 43(3), 296-316. https://doi.org/10.1080 /00913367.2013.857620

Krippendorff, K. (2011). Agreement and information in the reliability of coding. Communication Methods and Measures, 5(2), 93-112.

kumparanNews. (2020). Ibu kehilangan bayi korban rapid test: Postingan Jerinx Mewakili yang saya alami. Kumparan. Retrieved from https://kumparan.com/kumparannews/ibu-kehilangan-bayi-korban-rapid-test-postingan-jerinx-mewakili-yang-sayaalami-1uQYC2ZMkxp/1

Kusuma, S., \& P. Lubis, D. (2016). Media sosial dan kebijakan kapolri mengenai ,hate speech' (ujaran kebencian). Jurnal Komunikasi Pembangunan, 14(1), 151-159. https:// doi.org/10.46937/14201613556

Mangantibe, V. (2016). Ujaran kebencian dalam surat edaran kapolri nomor: Se/6/X/2015 tentang penanganan ucapan kebencian (hate speech). Lex Crimen, 5(1), 159-162.

Nastiti, A. (2020). Why Indonesia 's omnibus bill will not create jobs and only strengthen the oligarchy. The Conversation. Retrieved from https://theconversation.com/ why-indonesias-omnibus-bill-will-not-create-jobs-and-only-strengthen-the-oligarchy-147997

Noar, S. M. (2006). A 10-year retrospective of research in health mass media campaigns: 
Where do we go from here? Journal of Health Communication, 11(1), 21-42. https:// doi.org/10.1080/10810730500461059

Paterson, B. L., Thorne, S. E., Canam, C., \& Jillings, C. (2001). Meta-study of qualitative health research: A practical guide to meta-analysis and meta-synthesis. SAGE Publications Ltd.

Paz, M. A., Montero-Díaz, J., \& Moreno-Delgado, A. (2020). Hate speech: A systematized review. SAGE Open, 10(4), 1-12. https://doi.org/10.1177/2158244020973022

Permana, R., \& Ferdinan. (2020). Police arrest 10 admin suspects and makers of the demo group reject omnibus law. Voi.Id.

Pohjonen, M., \& Udupa, S. (2017). Extreme speech online: An anthropological critique of hate speech debates. International Journal of Communication, 11, 1173-1191.

Purnomo, A. (2020). Legal perspectives concerning hate speech in indonesia. Palarch's Journal of Archaelogy of Egypt/Egyptogy, 17(3), 544-554.

Rains, S. A., Levine, T. R., \& Weber, R. (2018). Sixty years of quantitative communication research summarized: lessons from 149 meta-analyses. Annals of the International Communication Association, 42(2), 105-124. https://doi.org/10.1080/23808985.20 18.1446350

Rains, S. A., Matthes, J., \& Palomares, N. A. (2020). Communication science and metaanalysis: Introduction to the special issue. Human Communication Research, 46(2-3), 115-119. https://doi.org/10.1093/hcr/hqaa007

Ritzer, G. (1990). Metatheorizing in sociology. Sociological Forum, 5(3).

Ross, K. (2018). Hate speech, free speech: The challenges of the online world. Journal of Applied Youth Studies, 2(3), 76-81. https://search.informit.org/doi/10.3316/informit.432967111162256

Ryanto, A. (2015). Eksistensi dan kedudukan hukum surat edaran kapolri tentang penanganan ujaran kebencian (hate speech). Jurnal Cahaya Keadilan, 3(2), 1. https:// doi.org/10.33884/jck.v3i2.961

SAFEnet. (2020). Indonesia digital rights situation report: The rise of digital authoritarian. SAFEnet. Retrieved from https://safenet.or.id/2020/10/digital-rights-situationreport-indonesia-2019-the-rise-of-digital-authoritarian/

Sari, I. D. (2016). Implikasi yuridis surat edaran kapolri mengenai penangan ujaran kebencian (hate speech) se/6/x/2015 dalam kebebasan berpendapat di media online. Jurnal Mahasiswa Fakultas Hukum. Retrieved from http://hukum.studentjournal. ub.ac.id/index.php/hukum/article/view/1698

Setkab. (2019). Communication ministry still imposes internet blackout in Papua and West Papua. Office of Assistant to Deputy Cabinet Secretary for State Documents \& Translation.

Subroto, I. M. I. (2014). The architecture of Indonesian publication index: A major Indonesian academic database. Telecommunication, Computing, Electronics and Control, 12(1), 1-5.

Taipale, S., \& Fortunati, L. (2014). Capturing methodological trends in mobile communication studies. Information Communication and Society, 17(5), 627-642. https:// doi.org/10.1080/1369118X.2013.862562

The Jakarta Post. (2015). Lawyers call for revocation of hate speech circular. Retrieved from https:/www.thejakartapost.com/news/2015/11/04/lawyers-call-revocation-hatespeech-circular.html

The Jakarta Post. (2018). Papua resident arrested for alleged hate speech against Indonesia. Wisnu, A., \& Wulandari, E. (2009). Blame game starts over misuse of law in Prita Mulyasari case. The Jakarta Post. Retrieved from https:/www.thejakartapost.com/ news/2009/06/05/blame-game-starts-over-misuse-law-prita-mulyasari-case.html 
Yong, C. (2011). Does freedom of speech include hate speech? Res Publica, 17, 385. Zhao, S. (1991). Metatheory, metamethod, meta-data-analysis: What, why, and how? Sociological Perspectives, 34(3), 377-390. https://doi.org/10.2307/1389517 Justito Adiprasetio is a lecturer in the Department of Journalism, Faculty of Communication Science, Universitas Padjadjaran. He researches and regularly writes on Indonesian journalism, media ecosystem and popular culture in scientific journals and mass media. In 2018/2019, Adiprasetio and his colleagues received a research grant from WhatsApp/Facebook to investigate misinformation in the 2019 Indonesian general election.

justito.adiprasetio@unpad.ac.id

Detta Rahmawan is a lecturer at the Faculty of Communication Science Universitas Padjadjaran. His works focus on ethnographic research and critical inquiries on digital media industry and dis/misinformation ecosystem.

Dr Kunto Adi Wibowo is a lecturer at Faculty of Communication Science Universitas Padjadjaran. His research focus is on misinformation/fake news on social media and social media's algorithm effects on political attitudes and behaviours.

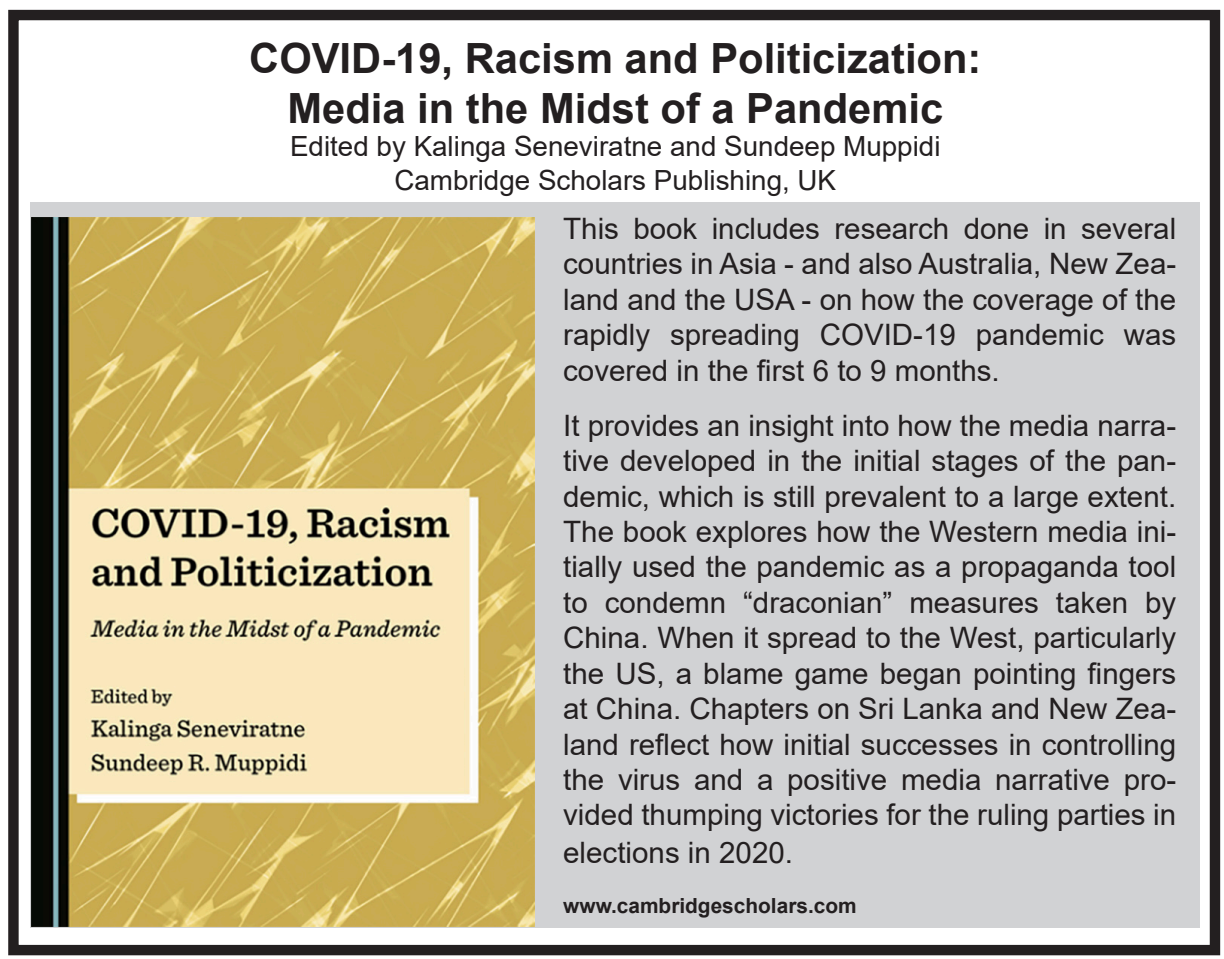

